\title{
Glimpses into Zhong Hong's educational background, with remarks on manifestations of the Zhouyi in his writings ${ }^{1}$
}

\author{
BERNHARD FUEHRER \\ School of Oriental and African Studies
}

\section{Introduction}

The two short accounts on the life of Zhong Hong (alt.: Rong) 鍾嵓 (467?-518) in the official dynastic histories both describe the author of the Shipin 詩品 (Kriterion poietikon or Classification of poets) as 'fond of learning' (hao xue 好學), 'thoughtful on the ratio [of matters]' (you si li 有思理), and 'understanding the Changes of Zhou' (ming Zhouyi 明周易). ${ }^{2}$ As Yan Zhitui 顏之推 (531c. 590) had noted, the Zhouyi (Changes of Zhou or Book of Changes) was-together with the Laozi 老子 or Daodejing 道德經 (Book of the Way and the Virtue) and the Zhuangzi 莊子—one of the so-called san xuan 三玄, the three core readings studied throughout the country at the time. ${ }^{3}$ It is thus not surprising that from the Later Han (25-220) to Zhong Hong's time, an enormous number of commentaries on the Zhouyi were written, only a limited number of which have survived to the present day. ${ }^{4}$ Although there is no indication that Zhong Hong himself had ever written down his insights on the Zhouyi, the compilers of his biography considered his accomplishment in this specialist field of studies noteworthy. The historians' short statement evokes the question as to whether this remark should be read as a subtle hint pointing the reader of Zhong Hong's writings towards a specific hermeneutic context.

Exposing myself to the calculated risk of over-emphasizing one aspect of the formation of Zhong Hong's intellect and critical mind, this case study

${ }^{1}$ Technical note: The following abbreviations are used for collectanea, etc.: $B Z Q S$ for Baizi quanshu 百子全書 (Photolithographic reproduction of the Shaoye shanfang 掃葉山房 edition, 1875. 8 vols; Hangzhou: Zhejiang Renmin chubanshe, [1984] 1985); CSJC for Congshu jicheng [chubian] 叢書集成 [初編]; HWCS for Cheng Rong 程榮 (comp.), Han Wei congshu 漢魏叢書. (Reprint of a Wanli 萬曆 (1573-1620) edition (with alterations). Changchun: Jilin Daxue chubanshe, 1992); LYJC for Yan Lingfeng 嚴靈峰 (comp.), Wuqiubei zhai Lunyu jicheng 無求備齋論語集成. (30 cases; Taibei: Yiwen yinshuguan, 1966); SBBY for Sibu beiyao 四部備要. (100 vols; Beijing: Zhonghua shuju, 1989); SBCK for Sibu congkan [zhengbian] 四部叢刊[正編]. (100 vols; Taibei: Taiwan Shangwu yinshuguan, 1979); SSJZS for Shisan jing zhushu [fu jiaokanji] 十三經注疏[附校勘記]. (Photolithographic reproduction of the Nanchang edition, 1815/1816. 8 vols; Taibei: Yiwen yinshuguan, $\left.{ }^{10} 1985\right)$; SYCS for Zhang Junheng 張鈞衡 (comp.), Shiyuan congshu 適園叢書. (Published by the compiler, 1913-16); ZTDZ for Zhengtong Daozang 正統道藏; ZZJC for Zhuzi jicheng 諸子集成. (8 vols; Beijing: Zhonghua shuju, [1954] 1993).

${ }^{2}$ See Yao Cha 姚察 and Yao Silian 姚思廉, Liang shu 梁書 (3 vols; Beijing: Zhonghua shuju, [1973] 1987), 49: 694-69, esp. 694 and Li Yanshou 李延壽 Nan shi 南史 (6 vols; Beijing: Zhonghua shuju, [1975] 1987), 72: 1778f., esp. 1778. Note that the version in the Liang shu includes an excerpt from the preface ( $x u$ 序) to the Shipin. For discussions and translations of these two biographies see Hellmut Wilhelm, 'A note on Chung Hung and his Shih-p'in', in Chow Tse-tsung (ed.), Wen-lin. Studies in Chinese humanities (Madison: University of Wisconsin Press, 1968), 111-20, the remarks on this article by Dirk Reiner Jonker in his review in T'oung Pao 59 (1973), 277-82, and Bernhard Führer, 'Zur Biographie des Zhong Hong', in Acta Orientalia Academiae Scientiarum Hungaricae, 46.2/3 (1992/93), 163-87. For the most comprehensive chronological biography of Zhong Hong see Cao Xu 曹旭, ‘Zhong Hong nianbiao’鍾崍年表, in his Shipin yanjiu 詩品㸴究 (Shanghai: Shanghai Guji chubanshe, 1998), 345-64.

${ }^{3}$ See Zhou Fagao 周法高, Yan shi jiaxun huizhu 顏氏家訓彙注 (Taibei: Academia Sinica, 1960 [Zhongyang Yanjiuyuan Lishi Yuyan Yanjiusuo zhuankan, 41]), 43 [ch. 8].

${ }^{4}$ For some of these writings see: Jian Boxian 簡博賢, Jincun nanbeichao jingxue yiji kao 今存南北朝經學遺籍考 (Taibei: Liming wenhua shiye, 1975); Huang Qingxuan 凉慶萱, Wei Jin nanbeichao Yixue shu kaoyi 魏晉南北朝易學書考佚 (Taibei: Youshi wenhua, 1975); Xu Qinting 徐芹庭, Liang Han shiliu jia Yi zhu chanwei 兩漢十六家易注闡微 (Taibei: Wuzhou chubanshe, 1975) as well as the relevant bibliographical chapters in the dynastic histories.

Bullelin of SOAS 67, 1, (2004), 64-78. (C) School of Oriental and African Studies. Printed in the United Kingdom 
attempts to shed some light on the role of the Zhouyi in his intellectual biography. The following glimpses into his educational background are thus divided into an outline discussion of influences on the level of jiaxue 家學, that is, teachings transmitted within the clan, and short remarks on the background of related teachings at the Imperial University (guozixue 國子學 or guoxue 國學). In the third part, we shall explore a working hypothesis concerning underlying structural concepts of the Shipin. ${ }^{5}$

\section{The Zhong clan's jiaxue}

The fall of the Han resulted in the political and moral breakdown of the central authority and strengthened the awareness of the uniqueness of the individual. ${ }^{6}$ Whereas the majority of Han thinkers - the most famous exception being Wang Chong 王充 (27-c. 79) - did not challenge the concepts transmitted in the canonized writings, a distinctively critical attitude towards the ideas attributed to authorities such as Confucius or Laozi became more common with the leading thinkers from the Wei period (220-265) onward. During the relatively short period of a few centuries, idiosyncrasy in character and style was regarded as a highly laudable quality, and the discursive language concerning uniqueness was greatly enriched. Despite the strengthening of the notions and perceptions of non-uniformity and non-conformity, ancestry, clan and place of origin remained of utmost importance for a person's positioning and self-positioning in society. To expose children to the study of their ancestors' scholarly achievements was one of the educative mechanisms, the aim of which was to strengthen clan-awareness. Consequently, appreciation of their writings was perceived as an integral part of the curriculum for later generations. ${ }^{7}$ The educationally imprinted offspring thus became the vehicle by which the ancestors' contributions to civilization were transmitted. ${ }^{8}$

\footnotetext{
${ }^{5}$ In addition to relying on my Chinas erste Poetik. Das Shipin (Kriterion Poietikon) des Zhong Hong (Dortmund: projekt verlag, 1995 [edition cathay, 10]), which includes an extensively annotated German translation of the Shipin, and some of my earlier articles such as 'High wing and true bone, defying ice and frost. Illustrative remarks on the Shipin of Zhong Hong', in Bochumer Jahrbuch zur Ostasienforschung, 19 (1995), 51-70, the third part of this article is also indebted to Zhang Bowei's 張伯偉 outstanding study of the relationship between the Shipin and the Zhouyi; see his Zhong Hong Shipin yanjiu 鍾嶸詩品䂰究 (Nanjing: Nanjing Daxue chubanshe, 1993), 38-51 and the excerpt published as 'Lun Zhong Hong Shipin de sixiang jichu' 論鍾喍詩品的思 想基礎, in Chugoku bungko-hō 中國文學報, 46 (1993), 50-67, esp. 50-58.

${ }^{6}$ See Yü Ying-shih, 'Individualism and the neo-Taoist movement in Wei-Chin China' in Donald J. Munro (ed.), Individualism and holism. Studies in Confucian and Taoist values (Ann Arbor: University of Michigan, 1985), 121-55 and Bernhard Fuehrer, 'Considerations on the question of individualism and the role of the individual in early Chinese thought', in Asia-Europe Foundation (ed.), The role of the individual vis-à-vis family, society and state in Asia and Europe (Singapore: Asia-Europe Foundation, 2001), 1-31.

${ }^{7}$ For a well-known example see Fan Ye 范瞱, Hou Han shu 後漢書 (12 vols; Beijing: Zhonghua shuju, [1965] 1987), 67: 2213f., where the ancestry of Kong Yu 孔昱 (zi: Yuanshi 元世) is traced back to Kong Anguo 孔安國 (d. c. 100 B.C.). The commentary by Li Xian 李賢 (651-684) et al. thus identifies the subject of jiaxue in this case as the study of the Shangshu 尚書 (Book of Documents). Later scholars, such as Wu Zhi 吳植 or Qian Qianyi 錢謙盆 (1582-1664) used the term jiaxue yuanyuan 家學淵源 which established lines of scholarly derivation parallel to physical genealogies; see e.g. Wu Zhi's preface ( $x u$ 序) to Qu You's 睢祐 (1347-1433) Jiandeng xinhua in Zhou Yi 周夷, Jiandeng xinhua wai erzhong 剪燈新話外二種 (Shanghai: Gudian wenxue chubanshe, 1957), 5. See also Li Ruzhen 李汝珍, Jinghuayuan 鏡花緣 (2 vols; Beijing: Renmin wenxue chubanshe, [1955] 1986), 473 [ch. 65] for an appearance of this term in a merely ironic context. For an overview of the private education of children from aristocratic families see Qian Mu 錢穆 'Lüelun Wei Jin nanbeichao xueshu wenhua yu dangshi mendi zhi guanxi’ 略論魏晉南北朝學術文化與當時門第之關 係, in his Zhongguo xueshu sixiangshi luncong 中國學術思想史論叢 (8 vols; Taibei: Dongda tushu, 1977), vol. 3, 134-99.

${ }^{8}$ On the expression jiachuanxue 家傳學, which emphasizes this aspect, see Zhongwen da cidian 中文大辭典 (10 vols; Taibei: Zhongguo Wenhua Daxue, [1973] 1985), 7322.213.
} 
In other words, jiaxue was a most eminent component of the celebration of ancestors on the intellectual level.

In a fairly reliable reconstruction of Zhong Hong's genealogy, the earliest known member of the Zhong clan to distinguish himself as a scholar was Zhong Hao 鍾皓 ( $z i$ : Jiming 季明) who lived as a local celebrity in Changshe 長社 in Yingchuan 穎川 during the Later Han. ${ }^{9}$ After a career as an official, he retreated to a mountain, devoted himself to the study of poetry, taught over a thousand pupils and died at the age of sixty-nine..$^{10}$ Although it has been suggested that Zhong Hao's studies on poetic patterns (shilü 詩律) might have influenced Zhong Hong's interest in the shi 詩 genre, we need to note that the Zhong clan was primarily associated with the study of the Zhouyi.

In his commentary to the Shishuo xinyu 世說新語 (New account of tales of the world), Liu Jun 劉峻 (462-521) reports that Zhong You 鍾繙 (zi: Yuanchang 元常, 151-230), ${ }^{11}$ a grandson of Zhong Di, came from 'a poor family, was fond of learning, [and] made [exegetical] studies of the Changes of the Zhou and the Laozi'. ${ }^{12}$

The titles of these studies on the Zhouyi and the Laozi are elsewhere transmitted as Zhouyi xun 周易訓 (Glosses on the Changes of Zhou) and Laozi xun 老子訓 (Glosses on the Laozi). ${ }^{13}$ Apart from his role as a military leader and official at the end of the Han and during the Wei, and as Grand Tutor (taifu 太傅) to the crown-prince, Zhong You was also a celebrated calligrapher who specialized in lishu 隸書 (scribal style) and to whom a work on the dynamics of the brush is attributed. ${ }^{14}$ In his Shupin 書品 (Classification of calligraphers), Yu Jianwu 庵肩吾 (c.487-551) ranked him as one of the three most outstanding calligraphers (shang zhi shang 上之上); later generations referred to him and Wang Xizhi 王羲之 (303/321?-379) by the term 'Zhong Wang' 鍾王. ${ }^{15}$

Zhong You's sons, Zhong Yu 鍾毓 ( $z i$ : Zhishu 稚叔, d. 263) and Zhong Hui 鍾會 ( $z i$ : Shiji 士季, 225-264), followed in the footsteps of their father's scholarly contributions. ${ }^{16}$ Collections of the writings of both are attested,

${ }^{9}$ For Zhong Hao's biography see Hou Han shu, 62: 2064 and the quote from Xianxian xingzhuan 先賢行狀 in Pei Songzhi’s 裴松之 (372/360?-451) note to Wei shu 魏書 in Chen Shou 陳壽, Sanguo zhi 三國志 (5 vols; Beijing: Zhonghua shuju, [1959] 1987), 13: 391f. Hou Han shu, 62: 2064 states that his moral achievement was praised by contemporaries as exemplary (zhi de ke shi 至德可師). Changshe 長社 in Yingchuan 穎川 is in modern Changge xian 長葛縣 in Henan province.

${ }^{10}$ Owing to political indisposition, his two sons, Zhong Di 鍾迪 and Zhong Fu 鍾敷, did not pursue careers as officials; see Pei's note in Sanguo zhi, 13: 392.

${ }^{11}$ For Zhong You's biography see Sanguo zhi, 13: 391-9.

${ }^{12}$ Yang Yong 楊勇, Shishuo xinyu jiaojian 世說新語校箋 (Repr.; Taibei: Zhengwen shuju, 1988), 53 [ch. Yanyu 11]. Sanguo zhi, 13: 391 notes that Zhong Yu 鍾瑜, an elder clan member (zufu族父), brought Zhong You to Luoyang and supported his studies financially.

${ }^{13}$ See Yao Zhenzong 姚振宗, Sanguo yiwen zhi 三國藝文志 $(S Y C S), 1: 9 \mathrm{a}$ and 3: 21a-b. For his interest in the Zhouyi and the Laozi see also Pei's commentary in Sanguo zhi, 28: 786. For some of his prose writings (memorials, letters, etc.) see Yan Kejun 嚴可均 (comp.), Quan shanggu sandai Qin Han sanguo liuchao wen 全上古三代秦漢三國六朝文 (4 vols; Beijing: Zhonghua shuju, 1958), vol. 2, 1184-6 [Sanguo wen, 24: 5a-10a].

${ }^{14}$ Sanguo yiwen zhi, 3: 81a gives the title as Bishi tu 筆勢圖 (Charts on the dynamics of the brush). However, Yao Zhenzong also recounts that a text entitled Bishi lun 筆勢論 (On the dynamics of the brush) emerged from Zhong You's tomb during the Taikang era 太康(280-289) of Western Jin (265-317). Song Yi 宋翼, one of Zhong's pupils, became famous after studying this text and applying its teachings to xingshu 行書 (cursive style).

${ }^{15} \mathrm{cf}$. the various references to his achievement in calligraphy in William Raynolds Beal Acker, Some T'ang and pre-T'ang texts on painting (2 vols; Leiden: Brill, 1954 [Sinica Leidensia, 8]) and in Susan Bush and Hsio-yen Shih, Early Chinese texts on painting (Cambridge, MA: Harvard University Press, 1985).

${ }^{16}$ For biographies see Sanguo zhi, 13: 399f (Zhong Yu) and Sanguo zhi, 28: 784-97 (Zhong Hui). For an edition of Zhong Hui's biography with a good and useful modern commentary see Miao Yue 繆鋮, Sanguo zhi xuan三國志選 (Beijing: Zhonghua shuju, 1985), 127-43. 
fragments of which were re-compiled by Yan Kejun 嚴可均 (1762-1843). ${ }^{17}$ Moreover, both brothers are associated with studies on the Zhouyi.

The title of Zhong Yu's study on the Zhouyi is transmitted as Nan Guan Lu Yiyi 難管輅易義 which was, as indicated by the title, a refutation of Guan Lu's 管輅 (zi: Gongming 公明, 208-256) approach. ${ }^{18}$

According to his own account of his studies, Zhong Hui 'recited the Zhouyi at the age of eleven' and the Yiji 易記 (Notes on the Changes), a commentary on the Zhouyi written by his father, at the age of fourteen just before entering the Imperial University (taixue 太學). ${ }^{19}$ His keen interest in the Zhouyi and in the Laozi is reported in a number of sources-bibliographies list his commentary on the Laozi under slightly different titles. ${ }^{20}$ Although only fragments of this commentary have survived, eminent Tang (618-907) exegetes such as Li Shan 李善 (c.630?-689), in his commentary to Xiao Tong's 蕭統 (501-531) Wenxuan 文選 (Selections of refined literature), and Lu Deming 陸德明 (556-627), in his Jingdian shiwen 經典釋文 (Explanations of terms in the classics), referred to and quoted from it. ${ }^{21}$

Zhong Hui's treatises on the Zhouyi include the titles Zhouyi jinshen lun 周易盡神論 (On fully expressing the spirit of the Changes of Zhou), Zhouyi wu huti lun 周易無互體論 (On the Changes of Zhou having no overlapping trigrams) and Zhouyi lun 周易論 (Dissertation on the Changes of Zhou). ${ }^{22}$ All we know about his Zhouyi wu huti lun is that it was no longer extant when the bibliographic chapter of the Sui shu 隋書 (History of the Sui) was compiled. Nevertheless, its title indicates his position in a major scholarly dispute, an

\footnotetext{
${ }^{17}$ For the Zhong Yu ji 鍾毓集 (5 juan) and the Zhong Hui ji 鍾會集 (10 juan) see Wei Zheng 魏徵, Sui shu 隋書 (6 vols; Beijing: Zhonghua shuju, [1973] 1987), 35: 1060; Liu Xu 劉昫, Jiu Tang shu舊唐書 (16 vols; Beijing: Zhonghua shuju, [1975] 1987), 47: 2057; Ouyang Xiu 歐陽修, Xin Tang $s h u$ 新唐書 (20 vols; Beijing: Zhonghua shuju, 1975), 64: 1580. For redactions of the latter, entitled Wei Zhong situ ji 魏鍾司徒集 (1 juan) and Zhong situ ji xuan 鍾司徒集選 (1 juan), see Zhongguo congshu zonglu 中國叢書綜錄 (Repr.; 3 vols; Shanghai: Guji chubanshe, 1982), vol. 2, 1203. For compilations of fragments of their works see also Quan shanggu sandai Qin Han sanguo liuchao wen, vol. 2, 1186-91 [Sanguo wen, 24: 10a-11a (for Zhong Yu) and 25: 1a-8a (for Zhong Hui)].

${ }^{18}$ For the Nan Guan Lu Yiyi see Sanguo yiwen zhi, 1: 13a; on Guan Lu see Sanguo zhi, 29: 811-30. For his studies on the Zhouyi see the quotes from Lu biezhuan 輅別傳 in Pei's note in Sanguo zhi, 29: 812f. The text of Zhong Yu's study is lost.

${ }^{19}$ See the quote from Zhong Hui's 'Zhang Furen zhuan' 張夫人傳 (alternative title: 'Zhong Hui mu zhuan'鍾會母傳) in Pei's commentary in Sanguo zhi, 28: 785. The title of the Yiji is alternatively given as Cheng Hou Yiji 成侯易記 (Marquis Cheng's notes on the Changes); Cheng Hou was Zhong Yao's posthumous name.

${ }^{20}$ See e.g. Sanguo yiwen zhi, 1: 9a and 3: 21a. On his scholarly interest see also Pei's commentary in Sanguo zhi, 28: 786: '[Zhong Hui] was especially fond of the Changes and the Laozi' (特好易老子). His commentary on the Laozi is listed in Sui shu, 34: 1000 as Laozi Daode jing 老子道德經 (2 juan); Jiu Tang shu 舊唐書, 47: 2027 has Laozi (2 juan); and Xin Tang shu, 59: 1514 refers to it as Zhong Hui zhu 鍾會注 (2 juan) in its section of works on the Laozi. For a short fragmentary passage from Laozi Zhong shi zhu 老子鍾氏注 (1 juan) see Wang Renjun 王仁俊 (comp.), Yuhan shangfang ji yi shu xubian sanzhong 玉函山房輯佚書續編三種 (Shanghai: Shanghai Guji chubanshe, 1981), 196. A passage from his commentary on the Laozi is also found in Li Lin's 李霖 (fl. 1172) Daode zhenjing qushan ji 道德真經取善集(ZTDZ); for a translation and short discussion of it see Rudolf $\mathrm{G}$. Wagner, The craft of a Chinese commentator. Wang Bi on the Laozi (Albany: State University of New York Press, 2000 [SUNY Series in Chinese Philosophy and Culture]), 140-49, 327.

${ }^{21}$ See Lu Deming 陸德明, Jingdian shiwen 經典釋文 (3 vols; Shanghai: Shanghai Guji chubanshe, 1985), vol. 1, 64 [Xulu; 1: 32b] where it is referred to as Zhong Hui [Laozi] zhu er juan 鍾會 [老子] 注二卷. For a convenient list of quotes from his works, including from his commentary on the Laozi, in the Six Officials' edition of the Wenxuan (SBCK; vol. 92) see Liu chen zhu Wenxuan yinshu yinde 六臣注文選引書引得 (Index to the titles quoted in the commentary on Wen Hsüan) (Peking: Yenching University, 1935 [Harvard-Yenching Institute Sinological Index Series, 26]), 117.

${ }_{22}^{2}$ For references to his Zhouyi jinshen lun (1 juan) and Zhouyi wu huti lun (3 juan) see Sui shu, 32: 910; for his Zhouyi lun (4 juan) see Jiu Tang shu, 46: 1968 and Xin Tang shu, 57: 1425. None of these texts has survived.
} 
assumption which is also confirmed by historical accounts. ${ }^{23}$ It is thus evident that Zhong Hong opposed the reading of the Zhouyi based on 'overlapping trigrams' or 'internal trigrams' (huti 互體), an approach which can be traced back to the Zuo zhuan 左傳 (Traditions of Zuo [Qiuming]). ${ }^{24}$ After it was promulgated by Jing Fang 京房 (77-37 B.C.), later Han scholars such as Zheng Xuan 鄭玄 (127-200), Yu Fan 虞翻 (c.164-233) and others showed a predilection for interpreting hexagrams according to this method. ${ }^{25}$ As an exegetic strategy, it is based on the conviction that the hexagrams need to be perceived as being composed of four trigrams. In addition to the two main trigrams arranged one above the other (i.e. lines 1, 2, 3 and lines 4, 5, 6), two additional trigrams (huti) are deemed to be represented by lines 2, 3, 4 and 3, 4, 5. ${ }^{26}$

Following the critical approach towards Zheng Xuan's exegesis as developed in the Jingzhou 荆州 circle, Wang Bi 王崸 (226-249) condemned those who applied the huti method (and a number of other approaches) as follows: ${ }^{27}$

... artificial doctrines spread everywhere [and] it is indeed difficult to keep account [of it]. [When] the overlapping trigrams prove insufficient, [they] go on to the trigram change. [When] the trigram change proves also insufficient, [they] push on further to the Five Agents. Once its origin is lost, the [interpretative] cleverness becomes increasingly boundless. Even if [they] occasionally get [something], [they] grasp absolutely nothing of the concepts. This is probably all due to the fact that [they] concentrate on the images [and thus] forget the ideas. ${ }^{28}$

\footnotetext{
${ }^{23}$ See e.g. the passage '[Zhong] Hui argued that there are no 'overlapping trigrams' in the Changes' (會嘗論易無互體) in Sanguo zhi, 28: 795.

${ }^{24}$ See e.g. Du Yu’s 杜預 (222-284) commentary and Kong Yingda's 孔穎達 (574-648) subcommentary in Chunqiu Zuo zhuan zhengyi 春秋左傳正義 (SSJZS; vol. 6), 164 [Zuo zhuan: Zhuang 22; 9: 25a].

${ }^{25}$ See the quote from Wang Yinglin's 王應麟 (1223-96) preface to Zheng shi Zhouyi 鄭氏周易 (Mr. Zheng's Changes of the Zhou; completed 1273) in Lou Yulie 樓宇烈, Wang Bi ji jiaoshi 王弼集校釋 (2 vols; Beijing: Zhonghua shuju, 1980), vol. 2, 612. See also Gao Heng 高亨, 'Zuo zhuan Guoyu de Zhouyi shuo tongjie' 左傳國語的周易說通解, in his Zhouyi zalun 周易雜論 (Ji'nan: Qi Lu shushe, 1979). For Jing Fang's approach see his Jingshi Yizhuan 京氏易傳 (SBCK; vol. 2 or $H X C S, 1-13)$. On Yu Fan and the application of so-called 'artificial doctrines / theories' see the summary in Edward L. Shaughnessy, 'Commentary, philosophy, and translation: reading Wang Bi's commentary to the Yi jing in a new way', in Early China, 22 (1997), 221-45, esp. 224-9.

${ }^{26}$ For examples see: Lou Yulie, Wang Bi ji jiaoshi, 612; Richard Wilhelm, I Ging. Das Buch der Wandlungen (Düsseldorf: Eugen Diederichs Verlag, [1956] 1981), 328-30; Marie-Ina Bergeron, Wang Pi. Philosophe du non-avoir (Taibei: Institut Ricci, 1986), 33f., etc.

${ }^{27}$ On Wang Bi's relationship to the scholarly circles and the tradition at Jingzhou see Tang Yongtong 湯用䑣, 'Wang Bi zhi Zhouyi Lunyu xinyi' 王崸之周易論語新義, in Tang Yongtong xueshu lunwen ji 湯用䑣學術論文集 (Beijing: Zhonghua shuju, 1983), 264-79, esp. 266f. This article was first published in Tushu jikan 圖書季刊 (NS), 4 (1943), 28-40, and is also available in a (not very reliable) English translation prepared by Walter Liebenthal and published in Harvard Journal of Asiatic Studies 10 (1947), 124-61. See also Lin Lizhen 林麗畺, Wang Bi ji qi Yixue 王崸及其易學 (Taibei: Taiwan Guoli Daxue, 1977 [Wenshi congkan, 47]), 25-34; and Wang Xiaoyi 王曉毅, 'Jingzhou guanxue yu sanguo sixiang wenhua’ 荆州官學與三國思想文化, in Kongzi yanjiu 孔子㗑究, 1994/1, 44 49. For a different approach see Yu Yingshi 余英時, 'Han Jin zhi jishi zhi xin zijue yu xin sichao'漢晉之際士之新自覺與新思潮, in Xinya xuebao 新亞學報, 4/1 (1959), 25-144. On the background to Wang Bi's studies of the Zhouyi see Howard L. Goodman, Exegetes and exegesis of the Book of Changes in the third century A.D.: historical and scholastic contexts for Wang Pi (unpublished PhD dissertation; Princeton University, 1985).

${ }^{28}$ Wang Bi, Zhouyi lüeli 周易略例, in Zhouyi zhu 周易注 (SBBY; vol. 1), 91 [Ming xiang]: ... 僞說滋漫, 難可紀矣。互體不足, 遂及卦變。卦變又不足, 推致五行。一失其原, 巧愈彌甚。縱復或値, 而義无所取。蓋存象忘意之由也; Lou, Wang Bi ji jiaoshi, vol. 2, 605. For another useful modern commentary on the Zhouyi lüeli see Hou Qiudong 侯秋東, Wang Bi Yixue zhi yanjiu王弼易學之㸴究 (Taibei: Jiaxin shuini gongsi wenhua jijinhui, 1976 [Jiaxin shuini gongsi wenhua jijinhui yanjiu lunwen, 282]), 9-52. My translation is adapted from Richard John Lynn, The Classic of Changes. $A$ new translation of the I Ching as interpreted by Wang Bi (New York: Columbia UP, 1994 [Translations from Asian Classics]), 32. Compare Bergeron, Wang Pi, 111, 168 and the annotations to Zhouyi lüeli (HWCS), 14-18.
} 
Whereas nearly all scholars of the Han and Wei periods applied the huti-method, Wang Bi and Zhong Hui opposed this reading and promulgated a different approach. ${ }^{29}$ Since Zhong Hui's studies on the Zhouyi and on the Laozi fell into oblivion (at least after the Mongol dynasty) and Wang Bi became one of the most celebrated geniuses in Chinese intellectual history, we may also note that Wang Bi's biography in Wei shu 魏書 (History of the Wei) is added in a commentarial note to the biography of Zhong Hui. ${ }^{30}$ However, both were well-known scholars of their time and shared not only insights and methodological approaches but also a close personal relationship which involved scholarly debates and friendship. ${ }^{31}$

According to an account of the Zhong clan (from Yingchuan) in Xin Tang shu 新唐書 (New history of the Tang), Zhong Hong was a direct descendant of Zhong Hao, Zhong You and Zhong Yu. ${ }^{32}$ Scholars such as Liu Zhiji 劉知幾 (661-721), Shen Gua 沈括 (1031-95) and others had, however, rightly pointed out that these genealogies are notoriously problematic and by no means reliable, for the authority of a particular person was emphasized by and perceived as a function of the construction of ancestral lines of paradigms. ${ }^{33}$ Although the sources show some divergences, a presumably more reliable reconstruction of Zhong Hong's genealogy suggests that he was an offspring of the branch deriving from Zhong Yan 鍾演, a younger brother of Zhong You. ${ }^{34}$ It thus follows that the author of the Shipin was in fact not a direct descendant of the celebrated calligrapher Zhong You or of Zhong Hui, the clan's foremost student of the Zhouyi. Apart from identifying Zhong as a direct descendant of Zhong Hao, the specialist on shi poetry, we need to note that in the context of celebration of earlier clan members' scholarly achievements, that is to say, in the context of jiaxue, direct descent was considered to be of secondary importance. It thus seems reasonable to assume that the psychological mechanisms of personal identification with the achievements of previous generations emphasized clan membership over a particular person's lineage of direct physical ancestors.

\section{The Zhouyi at the Imperial University}

The two biographies of Zhong Hong both report that he was: 'a student at the Imperial University (guozisheng 國子生) during the Yongming period [483-493]'. ${ }^{35}$ Because of the political and military circumstances, the education system during the Northern and Southern Dynasties was, by and large, subject to discontinuity and instability. The Imperial University was established and abolished several times by a number of rulers under different circumstances

\footnotetext{
${ }^{29}$ See Shang Binghe 尚秉和, Jiao shi Yigu 焦氏易詁 (Beijing: Zhonghua shuju, 1991), juan 2; quoted from Zhang Bowei, Zhong Hong Shipin yanjiu, 43.

${ }^{30}$ For a short note on Wang Bi see Sanguo zhi, 28: 795. Pei Songzhi's commentary to Sanguo zhi, 28: 795f. offers a copy of He Shao's 何劭 (?-301) biography of Wang Bi. For an edition of this biography with useful modern notes see Lou, Wang Bi ji jiaoshi, vol. 2, 639-43 and 644-8 for some additional textual material on Wang Bi. For a discussion of sources on Wang Bi's biography and its context see also Bergeron, Wang Pi, 5-28 and Wagner, Craft of a commentator, 9-26.

${ }^{31}$ For examples of Wang and Zhong being named together as famous scholars see Pei's note in Sanguo zhi, 10: 316 or Sanguo zhi, 28: 794. For insights on their approaches towards the Laozi see Wagner, Craft of a commentator, 240-49.

${ }^{32}$ See Xin Tang shu, 75A: 3354f.

${ }^{33}$ See e.g. Pu Qilong 浦起龍, Shitong tongshi 史通通釋 (Taibei: Yiwen yinshuguan, 1978), 38-42 [Nei 2, ch. 5: Shijia], and Hu Daojing 胡道靜, Mengxi bitan jiaozheng 夢溪筆談校證 (2 vols; Shanghai: Shanghai Guji chubanshe, 1987), vol. 2, 743-84 [juan 24: Zazhi 1].

${ }^{34}$ For summaries of the problem of Zhong Hong's genealogy see Zhang Bowei, Zhong Hong Shipin yanjiu, 1-7, Cao Xu, Shipin yanjiu, 1-18, and Führer, 'Biographie des Zhong Hong', 168.

${ }^{35}$ Liang shu, 49: 694 and Nan shi, 72: 1778.
} 
and for different reasons. ${ }^{36}$ However, during the first month of the third year of the Yongming period 永明 (485), Xiao Ze 蕭賾 (440-493), emperor Wu 武 (r. 483-493) of Qi 齊, issued an edict to re-establish the Imperial University in order to re-focus the curriculum and scholarly interests on the classics. ${ }^{37}$

Notwithstanding that the historical sources provide no information concerning the exact year of Zhong Hong's entering the Imperial University, there is strong evidence that he-and his elder brother Zhong Wan 鍾岏-joined around two-hundred students who began their studies at the Imperial University in autumn $485 .{ }^{38}$ During the very same year, Wang Jian王儉 (452-489) had been appointed Chancellor of the Imperial University (guozi jijiu 國子祭酒) and subsequently taught the students at his residence. ${ }^{39}$ Zhong Hong addressed him by his posthumous name Wenxian 文獻 and in the Shipin as his teacher (shi 師). ${ }^{40}$ Zhong's biographies recount that Wang held him in high regard and that they enjoyed a close relationship. ${ }^{41}$

As indicated above, the reading of the Zhouyi transmitted within the Zhong clan can be described as closer to the reading suggested by Wang Bi than to that of Zheng Xuan. As for the studies of the Zhouyi at the Imperial University, it is frequently suggested that the curriculum at that time focused on Wang Bi's reading, and that Zhong Hong's studies of the Zhouyi concentrated almost exclusively on this tradition. ${ }^{42}$ This having been said, it is indeed noteworthy in the given context that the interaction between representatives and promoters of the $r u$ 儒 (i.e. the so-called Confucianist tradition represented mainly by the insights of Han scholars such as Ma Rong 馬融 [79-166], Zheng Xuan and their followers) and the xuan 玄 learning (i.e. the so-called Abstruse Learning represented here primarily by the interpretations suggested by Wang $\mathrm{Bi}$ and his followers) was by no means restricted to the scholarly level..$^{43}$ Regarding the curriculum at the Imperial University, this situation entailed a dispute about the chair for the study of the Zhouyi which went on for a considerable period of time. As Lu Cheng 陸澄 (425-494) had stated in a letter to Wang Jian, Zheng Xuan's reading of the Zhouyi was favoured for some time; during other periods, Wang Bi's reading played a predominant role. ${ }^{44}$

${ }^{36}$ See Xiao Zixian 蕭子顯, Nan Qi shu 南齊書 (3 vols; Beijing: Zhonghua shuju, [1972] 1987), 3: 46, 9: 143-5, 16: 315, etc. On the Nan Qi shu see also the illuminating remarks in Zhu Jihai 朱季海, Nan Qi shu jiaoyi 南齊書校議 (Beijing: Zhonghua shuju, 1984). For excerpts from relevant sources and summaries see: Ma Duanlin 馬端臨, Wenxian tongkao 文獻通考 (Repr.: 2 vols; Taibei: Taiwan Shangwu yinshuguan, 1987 [Shitong +通 ed.]), vol. 1, 389f. [juan 41]; Shen Jianshi 沈兼士, Zhongguo kaoshi zhidu shi 中國考試制度史 (Taibei: Taiwan Shangwu yinshuguan, [1969] ${ }^{5} 1981$ [Renren wenku] ), 57-65; Yang Chengbin 楊承涁, Qin Han Wei Jin nanbeichao jiaoyu zhidu 秦漢魏 晉南北朝教育制度 (Taibei: Taiwan Shangwu yinshuguan, 1978 [Xiulu wenku, 42]), 190-200; Lü Simian 吕思勉, Liang Jin nanbeichao shi 兩晉南北朝史 (2 vols; Shanghai: Shanghai Guji chubanshe, 1983), vol. 2, 1371-80, etc.

${ }_{37}^{3}$ See Nan Qi shu, 9: 143f. and Wenxian tongkao, vol. 1, 390.

38 Although disputed by some, there is a widely accepted consensus that he entered the Imperial University during that year.

${ }^{39}$ For Wang Jian's biographies see Nan Qi shu, 23: 433f. and Nan shi, 22: 590-96. For the duration of his activities at the Imperial University see Nan Qi shu, 23: 436 and compare Nan Qi shu, 16: 315 .

${ }_{40}$ Note that Wang Jian is the only poet addressed by his posthumous name in the Shipin; see Shipin in Helmut Martin (ed.), Suoyinben He shi Lidai shihua 索引本何氏歷代詩話 (2 vols; Taibei: Ch'eng-wen Publishing Co. and Chinese Materials and Research Aids Center, 1973 [Research Aids Series, 10]), 01010.23, 01010.25 and Führer, Chinas erste Poetik, 413-5 [4.3.17].

${ }^{41}$ See Liang shu, 49: 694 and Nan shi, 72: 1778.

${ }^{4}$ Although the degree to which Zhong Hong concentrated on Wang's readings is certainly open to discussion, it is a historical fact that at the time when Zhong studied there, the teaching of the Zhouyi at the Imperial University was not monopolized by Wang Bi's tradition. Nevertheless, to emphasize that Zhong concentrated almost exclusively on Wang's version became a widespread view; see e.g. Liao Weiqing 㦄蔚卿, Liuchao wenlun 六朝文論 (Taibei: Lianjing chubanshe, 1978), 361 (note 3), Luo Liqian 羅立乾, Zhong Hong shige meixue 鍾崍詩歌美學 (Taibei: Dongda tushu, 1990 [Canghai congkan]), 44, etc.

43 For an overview see Lü, Liang Jin nanbeichao shi, vol. 2, 1371-94.

${ }^{44}$ See Nan Qi shu, 39: 683f. For a partial translation of this letter see Wagner, Craft of $a$ commentator, $49 \mathrm{f}$. 
At the time when Zhong Hong studied at the Imperial University, a compromise had been reached in order to appease the tensions, and two 'doctorates' or chairs (boshi 博士) for the study of the Zhouyi were established. ${ }^{45} \mathrm{It}$ was exactly this coexistence of $r u$ and xuan scholarship for which Wang Jian and other erudites had argued. ${ }^{46}$ Zheng Xuan's reading was then taught along side Wang Bi's version, an approach which led not only to the study of both exegetical traditions but also paved the way to more syncretistic reading strategies. As a matter of fact, such an approach is attested for a number of scholars of the Yongming period, especially for Zhang Xu 張緒 (422-489) and He Yin 何胤 (446-531), the subsequent Chancellors of the Imperial University. ${ }^{47}$

\section{Manifestations of the Zhouyi}

In addition to the Shipin, the title of a further work by Zhong Hong is known to us. Unfortunately, however, the Ruishi fu瑞室賦 (Rhapsody on the auspicious mansion), a text composed in honour of He Yin, did not survive. All we know about this eulogy is that its 'wording was of outstanding classical beauty' ( $c i$ shen dian li 辭甚典麗)..$^{48}$ Apart from the Ruishi fu, two of his memorials are transmitted in Zhong Hong's biographies. ${ }^{49}$

Li Yanshou's 李延壽 (fl. 618-676) fairly sombre description of the sociopolitical reality of the day creates the context for a short memorial which was submitted by Zhong Hong at the beginning of the Jianwu 建武 (494-498) era. To begin with, his network of references echoes the whole range of learning from the Shangshu 尚書 (Book of Documents) to the Zhuangzi and so forth. His description of the rulers of antiquity as adopting a 'respectful posture and facing south' (gong ji nan mian 恭已南面) recalls the Confucianist version of wuwei 無爲 (non-interference/non-engagement) as known from the Lunyu 論語 (Analects). ${ }^{50}$ Further, if the same passage is read as alluding to the Zhouyi, the tension between the emperor's hyperactivity in attending to details in person, and teachings about grasping the essential as found in 'Shuo gua' 說卦 (Explanations of the trigrams) becomes transparent. ${ }^{51}$ The short dialogue between the emperor and one of his advisers, which follows the memorial in Nan shi 南史 (History of the Southern Dynasties), gives a clear indication that the author's critical remarks were well understood, though not well received by Xiao Luan 蕭鸞 (459-498), emperor Ming 明 (r. 494-498) of Qi. ${ }^{52}$ It goes without saying

\footnotetext{
${ }^{45}$ See the comment on the first year of the Tongming era (483) in Nan Qi shu, 39: 683.

${ }^{46}$ See Wang's reply to Lu Cheng in Nan Qi shu, 39: 685 where he rejects a mono-focused approach and holds that scholarly accomplishment can only be reached if both traditions are studied.

${ }^{47}$ See also the biographies of Liu Xian 劉㗔 (434-489) in Nan shi, 50: 1235-8 and Nan Qi shu, 39: 677-80 as well as the short note on his approach towards the Zhouyi in the Jinlouzi 金樓子 (BZQS; vol. 5), 1: 5b [Xing wang].

${ }_{48}$ Thus the praising formula in Liang shu, 49: 694 and Nan shi, 72: 1779.

${ }^{49}$ See Liang shu, 49: 694f. and Nan shi, 72: 1778. Cf. H. Wilhelm, 'Note on Chung Hung', 112f., Takamatsu Kōmei (Takaaki) 高松亨明, Shihin shōkai 詩品詳解' (Hirosaki: Hirosaki University, 1959), 132f., and Führer, 'Biographie des Zhong Hong', 173-9. The following remarks deal only with the memorial transmitted in Nan shi.

${ }_{50}$ Compare the final clause 'The Son of Heaven shall adopt a respectful posture and face south, and nothing more' (天子可恭已南面而已) of the memorial in Nan shi, 72: 1778 and the passage 'Shun .... adopted a respectful posture and faced south, and nothing more' ( 舜 ... 恭已正南 面而已矣) from Lunyu 15.5 in Lunyu zhushu 論語注疏 (SSJZS; vol. 8), 137 [15: 2b].

${ }^{51}$ See the passage 'The sage faces south and listens to the All-under-Heaven' (聖人南面而) 聽天下) in Zhouyi zhengyi 周易正義 (SSJZS; vol. 1), 184 [Shuo gua; 9:5a]. Cf. R. Wilhelm, I Ging, 250 and Lynn, Classic of Changes, 121.

${ }_{52}$ See Nan shi, 72: 1778. Cf. H. Wilhelm, 'Note on Chung Hung', 112; Takamatsu, Shihin shōkai, 132f.; Führer, 'Biographie des Zhong Hong', 174; and note the positive reaction to the memorial shown by Gu Hao 顧高.
} 
that the connection between Zhong Hong's pointing to the exemplary paradigms of high antiquity, and the teachings from the Zhouyi and the Lunyu, can be explored on a variety of levels. ${ }^{53}$ A closer look at this short admonishment and at Wang Bi's commentary to the Zhouyi reveals that Zhong's memorial reflects a number of Wang Bi's passages on proper rulership, e.g. on what was considered appropriate for a great sovereign (da jun zhi yi 大君之宜). ${ }^{54}$

The impact of the Zhouyi upon the structure of works such as the Wenxin diaolong 文心雕龍 (Patterning the heart and carving the dragon), the Shipin and the Shishuo xinyu 世說新語 (New account of tales of the world) has been indicated by a number of scholars. ${ }^{55}$ As for the Wenxin diaolong, perhaps the most obvious allusion to the Zhouyi is found in the programmatic chapter 'Xuzhi' 序志(Exposition of [the author's] intentions):

Positioning the principle and determining the names is exhibited in the number of the great Changes. For [the discussion of] literature, only forty-nine chapters are used. ${ }^{56}$

In other words, the structure of the Wenxin diaolong and its division into forty-nine chapters plus 'Xuzhi' is described by Liu Xie 劉妿 $(c .465-c .520)$ in direct reference to the clause 'The full number [lit.: great expansion] is fifty, of which forty-nine are used' in the 'Xici' 熬辭 (Appended phrases) commentary to the Zhouyi. ${ }^{57}$ Wang Bi's gloss on this passage, as transmitted in a quote in Han Kangbo's 韓康伯 (d. c. 385) commentary, reads:

Expanding the numbers of Heaven and Earth, what [the system] relies on are fifty, [of which] forty-nine are actually used whereas one is unused. Although [it is] not used, the use [of the others] is perpetuated by it; although [it is] not counted [as one of the numbers], the number [of the others] is completed by it. This is the supreme ultimate of changes. Forty-nine is the ultimate of numbers. ${ }^{58}$

${ }^{53}$ See e.g. He Yan's 何晏 (190-249) remark about appointing the right persons to administrative positions and thus 'ruling by non-interference' (任官得其人, 故無爲而治) in his note on Lunyu 15.5 in Lunyu jijie 論語集解 (Yonghuai tang 永懷堂 ed.; $S B C K$; vol. 2), 70. The legendary Shun's 舜 ruling by the principle of wuwei clearly contrasts with Xiao Luan's practice of governing.

${ }^{54}$ See e.g. Zhouyi zhu, p. 15 [19: Lin]: ‘... situated in the noble / exalted position, treading there [in such a way that he] manages to practise the Mean.... The wherewithal of a great sovereign need be like this and nothing more' (處於隹位, 嘹得其中...大君之宜, 如此而已) and ibid., p. 46 [64: weiji]: 'Due to [his] soft, compliant, civil and enlightened character, [he] occupies the noble / exalted position ... [and] achieves meritorious success in the conquest' ( 夫以柔順文明之質，居於 尊位...功斯克矣) and 'The Dao of Ferrying Complete ... he can take his ease here [and wait for the times to change]' (晛濟之道...而已逸焉 ); Lou, Wang Bi ji jiaoshi, vol. 1, 313 and vol. 2, 530. Translations adapted from Lynn, Classic of Changes, 257, 549f. Note that the commentary on Lin 臨 actually reverts to Laozi 47 and to Wang's commentaries on Laozi 3 and 49; see Lou, Wang Bi ji jiaoshi, vol. 1, 314.

${ }^{55}$ A close connection between Wenxin diaolong and Shipin with Zhouyi was, though not expressiv verbis, suggested by Zhang Xuecheng 章學誠(1738-1801); see Ye Yng 葉瑛, Wenshi tongyi jiaozhu 文史通義校注 (2 vols; Beijing: Zhonghua shuju, 1985), vol. 2, 559 [Shihua 1]. For a detailed discussion of passages alluding to and concepts influenced by the Zhouyi see, e.g., Deng Shiliang 鄧仕樑, 'Yi yu Wenxin diaolong. Yijing wenxue lilun zhi yi' 易與文心雕龍. 易經文學理論, 之一 in Chongji xuebao 崇基學報, 9.1 (1969), 72-83.

${ }^{56}$ Fan Wenlan 范文瀾, Wenxin diaolong zhu 文心雕龍注 (Repr.; Taibei: Taiwan Kaiming shudian, [1958] 1985), 10: 21b. Note that a number of commentators on the Wenxin diaolong suggest the reading da yan 大衍 for da yi 大易 in order to bring the passage into accordance with the clause to which it refers; see, e.g., Li Yuegang 李曰剛, Wenxin diaolong jiaoquan 文心雕龍抟詮 (2 vols; Taibei: Guoli Bianyiguan, 1982), vol. 2, 2317, 2324. 60.

${ }^{57}$ Zhouyi zhu, 51 [Xici. Shang]. Compare R. Wilhelm, I Ging, 287 and Lynn, Classic of Changes,

${ }^{58}$ Zhouyi zhu, 51: 演天地之數, 所賴者五十也。實用四十有九, 則其一不用也。不用而用以之通, 非數而數以之成。斯易之太極也。四十有九, 數之極也; Lou, Wang Bi ji jiaoshi, vol. 2, 547. Cf. Lynn, Classic of Changes, 60. On the use of forty-nine (i.e. fifty minus the unused one) stalks in the yarrow-stalk oracle see R. Wilhelm, I Ging, 336. 
An analogous remark can be made concerning the structure of the Shishuo xinyu, the total number of chapters of which plays a subtle but pertinent role. Thirty-six is half of seventy-two, the famous number explained by among others Wang Su 王肅 (195-256) as the number of days which fall on each of the Five Agents (wu xing 五行) in a year of 360 days. ${ }^{59}$

Similarly, the number of entries or paragraphs in each of the three sections in the Shipin has been subject to speculation. ${ }^{60}$ Due to alterations in the textual arrangement, we find divergent numbers of entries in different redactions of the Shipin. Even so, we may divide the shangpin 上品 (upper grade) into twelve, the zhongpin 中品 (middle grade) into thirty-nine, and the xiapin 下品 (lower grade) into seventy-two entries. ${ }^{61}$ Another such case can probably be argued for the fact that Zhong Hong only integrated thirty-six out of the over 120 poets discussed in the Shipin into his scheme of derivation from either the Shijing 詩經 (Book of Songs) or the Chuci 楚辭 (Songs of Chu). Although it seems that only the number of entries in the shangpin (i.e. 12), the xiapin (i.e. 72) category, and the number of poets for which the origin from one of the main fountainheads of poetry is stated (i.e. 36), can convincingly relate to speculative numerology, the deeper meaning of these numbers as formative structural elements of the Shipin remains open to speculation and further discussion.

Zhong Hong's attempt to trace poets' idiosyncrasies in style and character as well as their preferred subject-matter back to a two-fold origin of (pentasyllabic) shi-poetry, can be linked to one of the basic concepts developed by Wang Bi. In his commentary to the Laozi, Wang Bi had formulated the principle of 'using one to unite many' (yi gua tong zhong 以寡統衆). ${ }^{62}$ This concept figures prominently in his 'Zhouyi lüeli' 周易略例 (Outline of the Changes of Zhou), including the negation of its inversion (per privantiam contrarii): 'the many cannot govern the many' (zhong bu neng zhi zhong 衆不能 治衆). ${ }^{63}$ Whereas these points of reference are primarily perceived in the context of rulership and political philosophy, Wang's notes on the passages 'I wish [to do] with no speech' ( $y u$ yu wu yan 予欲無言) and on 'my way is linked together by [the] One' (wu dao yi yi guan zhi 吾道一以貫之) in his Lunyu shiyi 論語釋疑 (Explications on doubtful [points in He Yan's collected explanations] on the Lunyu) address a significantly disparate philosophical level. ${ }^{64}$ The

\footnotetext{
${ }^{59}$ See Wang Su's commentary to Kongzi jiayu 孔子家語 (SBBY; vol. 52), 39 [juan 6, ch. 24: Wudi]. For an enlightening collection and discussion of related textual sources see Wen Yiduo 聞一多, 'Qishier' 七十二 in Wen Yiduo quanji 聞一多全集 (4 vols; Shanghai: Kaiming shudian, 1948), vol. 1, 207-220. Concerning the function of the number thirty-six see Han Kangbo's commentary in Zhouyi zhu, 52 [Xici. Shang]; Lou, Wang Bi ji jiaoshi, vol. 2, 549. See also Lynn, Classic of Changes, 61 and R. Wilhelm, I Ging, 288 on the thirty-six yarrow stalks required by one yang line (yang yao 陽爻).

${ }^{60}$ See Cao Xu, Shipin yanjiu, 94-103.

${ }^{61}$ Note that I do not refer to the number of poets discussed in one of these sections but to the number of paragraphs or headings for some entries may discuss a group of poems composed by different persons. In other cases, comments on more than one poet appear under one heading.

${ }^{62}$ See the commentary on Laozi 11 in his Laozi zhu 老子注 (ZZJC; vol. 3), 6: yi gua tong zhong 以寡統衆 (reading 寡 for the scribal error實); Lou, Wang Bi ji jiaoshi, vol. 1, p. 27. See also Richard John Lynn, The Classic of the Way and Virtue. A new translation of the Tao-te ching of Laozi as interpreted by Wang Bi (New York: Columbia UP, 1999), 69.

${ }^{63} \mathrm{See}$ the passages 'The many cannot govern the many; that which governs the many is the utmost solidary [the One]' (夫衆不能治衆。治衆者, 至寡者也) and 'The rare is what the many value’ (夫少者, 多之所貴也 ) in Zhouyi lüeli, 67f. [Ming tuan]; Lou, Wang Bi ji jiaoshi, vol. 2, 591. Translations from Lynn, Classic of Changes, 25; cf. Bergeron, Wang Pi, 146.

${ }^{64}$ See the passage ju ben tong mo in Wang Bi's commentary on Lunyu 17.17 as quoted by Huang Kan 皇㑆 (485-545) in his Lunyu yishu 論語義疏 (Kaitokudō 懷德堂 ed.; LYJC), 9: 15a; Lou, Wang Bi ji jiaoshi, vol. 2, 633. For the similar expression zhi yi tong zhong zhi dao 執一統毷 之道 see his commentary on Lunyu 4.15 in Lunyu yishu, 2: 29b; Lou, Wang Bi ji jiaoshi, vol. 2, 622. Note that the prominent passage yi yi guan zhi is echoed in Han Kangbo's commentary in Zhouyi zhu, 56 [Xici. Xia]; Lou, Wang Bi ji jiaoshi, vol. 2; 561.
} 
quintessence, verbalized here as 'to pick (lit.: lift) the root and unite the end(s)' (ju ben tong mo 舉本統末) and as 'to hold the One [firmly] and unite the many' (zhi yi tong zhong 執一統衆), is to conceive diversity by recognizing the one principle which is beyond the multiplicity of its manifestations. In his exposition to the Zhouyi, Wang Bi wrote:

Therefore, the reason for all the many to manage to coexist, is the master which necessarily leads to the One. The reason for all activities to manage to operate, is the source [of which] necessarily do not exist two. No thing behaves haphazardly; [they] necessarily follow their [own] principle. To unite them, there is a [common] progenitor; to bring them together, there is a [common] beginning. Therefore there is complexity but no chaos, multitude but no confusion. ${ }^{65}$

We can thus identify Wang Bi's remark on the judgements (tuan 彖) as the conceptual kernel of a principle on which Zhong Hong's approach towards constructing lines of poetic lineage is built. Wang Bi continued as follows:

This is why [if one] starts from what unites [all] and searches for it [i.e. the one which is behind], even though things are multitudinous, [one] then knows that it is possible to grasp the one which guides it. [If one] commences from its root in order to observe it, even though the concepts are very wide, [one] then knows that it is possible to cover [the many] with one single name. ${ }^{66}$

This philosophical basis for the systematization of an otherwise presumably confusing complexity was developed from the concept of 'All-under-heaven [ultimately] reverts to the same, though [through] different paths' (tianxia tong gui er shu tu 天下同歸而殊塗) first formulated in the 'Xici' commentary to the Zhouyi. ${ }^{67}$ It features not only in Wang Bi's writings on the Zhouyi but also in his commentary on the Laozi where we read:

Matters have a [common] progenitor and [the multitudinous] things have a [common] master. Although the paths differ, they revert to the same. ${ }^{68}$

In addition, this dictum is reflected and echoed in a number of philosophical writings roughly contemporary to Wang $\mathrm{Bi}$, such as in the Lunyu jijie 論語集解 (Collected explanations on the Lunyu) compiled by Wang Bi's mentor He Yan 何晏 (190-249) and others. ${ }^{69}$

It thus follows that Zhong Hong applied a philosophical concept which originated from a commentary to the Zhouyi closely associated with Confucius by tradition, and which was expanded by Wang $\mathrm{Bi}$, to his 'poetics' in order

${ }^{65}$ Zhouyi lüeli, 67 [Ming tuan]: 故衆之所以得咸存者, 主必致一也。動之所以咸運者, 原必無二。 物无妄然, 必由其理。統之有宗, 會之有元。故繁而不亂, 衆而不惑; Lou, Wang Bi ji jiaoshi, vol. 2, 591. My translation follows in part Shaughnessy, 'Commentary, philosophy, and translation', 236 and Lynn, Classic of Changes, 25. Cf. Bergeron, Wang Pi, 146f.

${ }^{66}$ Zhouyi lüeli, 67 [Ming tuan]: 故自統而尋之, 物雖衆, 則知可以執一御也。由本以觀之, 義雖博, 則知可以一名舉也; Lou, Wang Bi ji jiaoshi, vol. 2, 591. Cf. Bergeron, Wang Pi, 147 and Lynn, Classic of Changes, 25f.

${ }^{67}$ Zhouyi zhengyi, 169 [Xici. Xia; 8: 9b]. For other translations see R. Wilhelm, I Ging, 311f. and Lynn, Classic of Changes, 81.

${ }^{68}$ Laozi zhu, 28: 事有宗而物有主, 途雖殊而同歸也 ; Lou, Wang Bi ji jiaoshi, vol. 1, 126 (see also note 1). Cf. Lynn, Way and Virtue, 141f. (note 1).

${ }^{69}$ See e.g. the passage 'different paths but revert to the same end' (殊塗而同歸) in his gloss on Lunyu 2.16 in Lunyu jijie, 7. 
to gain a view beyond the diversity of poetic expression and creativity. ${ }^{70}$ In essence, he followed the principle of 'the One is the progenitor of the many' (gua zhe, zhong zhi zong ye 寡者, 衆之所宗也). After 'commencing from the roots', he 'observed' the development (you ben yi guan zhi 由本以觀之) and 'pushed' (tui 推) a poet's style back to its 'source' (yuan 源), traced his stylistic 'ancestor' ( $z u$ 祖), and identified his 'model' (xianzhang 憲章). ${ }^{71}$ What Wang Bi described from an all-embracing viewpoint, was epitomized by Zhong Hong and thus enabled him to create lineages of poetic development (liu 流) which ultimately revert to the two 'archetypes' of all pentasyllabic shi-poetry. In Wang Bi's language, the Shijing - though subdivided into the line deriving from 'Guofeng'國風 (Airs of the states) and that deriving from Xiaoya 小雅 (Minor elegantiae) - and the Chuci represent the 'origin/root' (ben 本) from which diversity is derived. Understanding the origin (zhi qi yuan 知其元) thus becomes a hermeneutic strategy through which diversity is systematized.

To explore the connection between the Zhouyi and the basic structure of the Shipin even further, we shall proceed by suggesting that Zhong Hong's scheme of poetic derivation reflects the triple meaning of $y i$ 易. ${ }^{72}$ The aspects of 'easy and simple' (yijian 易簡), 'changing' (bianyi 變易) and 'not changing' (bu $y i$ 不易) are integral parts of Zhong Hong's dynamic scheme of particular poets developing from their 'source' to their own styles of composing poems. Thus the formula 'A originates/derives from B' (A yuanchu yu 源出於 B) emphasizes what their pentasyllabic shi have in common with the 'source'. In the light of this vista, the ultimate 'sources' or 'roots' represent the kind of simplicity which qualifies them as 'archetypes'. In coherence with the principle of 'picking one to clarify [all]' (ju yi yi ming 舉一以明), Shijing and Chuci became the terms through which he attempted to explain, summarize and exemplify the essentials of the intermingled diversity of poetic creation. ${ }^{73}$ Thus, these 'archetypes' are seen as what 'unites the ends' (tong mo 統末), what 'unites the many' (tong zhong 統衆). Moreover, it is highly significant that Zhong Hong's scheme of poetic lineages focuses on (basic) characteristics, that is to say, on aspects which, in essence, did not change and which are therefore shared by all members of one lineage. In doing so, he certainly did not overlook the more or less eye-catching changes which occurred during the development of such a lineage. In cases where he compared poets and their pentasyllabic oeuvre directly to each other, his evaluative descriptions display a distinct preference for highlighting differences. These comparative comments constitute most valuable remarks on relative merits and demerits, achievements and failures.

Zhong Hong's perception of the allegorical technique xing 興 (lit.: 'to stimulate', 'to evoke') is perhaps one of the best known examples showing the

\footnotetext{
${ }^{70}$ As for Confucius allegedly putting some of the commentaries on the Zhouyi in order, see Sima Qian 司馬遷, Shiji 史記 (10 vols; Beijing: Zhonghua shuju, [1959] 1982), 47: 1937 and Edward L. Shaughnessy, 'I Ching 易經 (Chou I 周易)' in Michael Loewe (ed.), Early Chinese texts: a bibliographical guide (Berkeley: The Society for the Study of Early China and The Institute of East Asian Studies, University of California, 1993), 216-28, esp. 221.

${ }^{71}$ On the term xianzhang see Liji zhushu, 899 [Zhongyong; 53: 12b]. For a short discussion of the three derivative models see Führer, Chinas erste Poetik, 50-53.

${ }^{72}$ See Kong Yingda's 孔穎達 (574-648) quotes from Yiwei qian zuo du 易緯乾錅度 and from Zheng Xuan's 'Yizan Yilun' 易贊易論 (see Zhouyi Zheng zhu 周易鄭注; CSJC) in 'Lun yi zhi san ming'論易之三名 in Zhouyi zhengyi, 3 [Xu; 3a-4b].

${ }_{73}$ Zhouyi lüeli, 67 [Ming tuan]: 'This is why when the six lines of a hexagram intermingle, one can pick out one of them and use it to clarify what is happening, and as the hard ones and the soft ones supersede one another, one can establish which one is the master and use it to determine how all are ordered' (故六爻相錯, 可舉一以明也。剛柔相乘, 可以立主以定也); Lou, Wang Bi ji jiaoshi, vol. 2, 591. Translation from Lynn, Classic of Changes, 25.
} 
significance of the Zhouyi for his conceptions. ${ }^{74}$ In other cases, the Shipin bears testimony to a more amalgamating approach. I shall restrict myself to one example. As gauged from his praise of Cao Zhi's 曹植(192?-232?) poems and other paragraphs in the shangpin section, Zhong Hong's ideal of pentasyllabic shi-poetry is intrinsically grounded on dicta which derive from two philosophical strata, though the $r u$ tradition plays a dominant function. ${ }^{75}$ Clauses like

Their meaning is far-reaching, their wording is elegant. Their language twists and turns but hits the mark $^{76}$

from the Zhouyi, namely from the 'Xici' commentary, and famous maxims from the Lunyu such as

... [only when] refinement (style) and substance are properly balanced, then [we] have an accomplished person ${ }^{77}$

constitute the conceptual lifeblood and the fundamental pedigree on which his ideal is developed and built. Granting that both texts are part of the $r u$ tradition, we need to keep in mind that with Wang Bi's reading, the Zhouyi was considered an eminent part of the xuan tradition too, a development which was, as mentioned above, institutionalized by establishing two chairs for studies on the Zhouyi. ${ }^{78}$

In order to elucidate the paradigmatic function of the Lunyu for Zhong Hong's poetic ideal, we may combine sequences from Lunyu 6.18, and the metaphors used by Liu Xie with relevant passages from the Shipin. We thus identify Liu Zhen 劉楨 (d. 217) as a wild or crude (ye 野) 'eagle': substance prevailed over refinement. ${ }^{79}$ Wang Can 王粲 (177-217) would be described as a pedantic ( $s h i$ 史) 'pheasant': refinement prevailed over substance. ${ }^{80}$ And only

\footnotetext{
${ }^{74}$ Compare the passage 'The writing has already come to an end and the ideas (meaning/content) linger on' (文已盡而意有餘) in Shipin, 01001.33-34 with passages like 'words do not express ideas exhaustively' (言不盡意) and 'the sage establishes images in order to express [their] ideas exhaustively' (聖人立象以盡意) in Zhouyi zhu, p. 53 [Xici. Shang]; Lou, Wang Bi ji jiaoshi, vol. 2, 554. Note that Wang Bi used the concept of "catching the idea and forgetting the words' (得意而忘言) from chapter 'Waiwu'外物, one of the heterogeneous parts of Zhuangzi [see Guo Qingfan 郭慶藩 Zhuangzi jishi 莊子集釋 (ZZJC; vol. 3), 407] in his Zhouyi lüeli, 70f. [Ming xiang] stating: 'To express ideas exhaustively, there is nothing like images; to express images exhaustively, there is nothing like words' (盡意莫若象, 盡象莫若言) and 'Words are the means to clarify images; [once one] catches the image, [he] forgets the words. Images are the means to hold ideas; [once one] holds the idea, [he] forgets the image' (言者, 所以明象, 得象而忘言; 象者, 所以 存意, 得意而忘象); Lou, Wang Bi ji jiaoshi, vol. 2, 609. Cf. Bergeron, Wang Pi, $165 f$ and Lynn, Classic of Changes, 31.

${ }^{75} \mathrm{On}$ this and the following paragraph see Führer, Chinas erste Poetik, 122f. For another approach towards Zhong Hong's ideal poetry see Cha Chu Whan, 'On enquiries of ideal poetry. An instance of Chung Hung', in Tamkang Review, 6.2/7.1 (1975/1976), 43-54.

${ }^{76}$ Zhouyi zhu, 57 [Xici. Xia]: 其旨遠, 其辭文, 其言曲而中; Lou, Wang Bi ji jiaoshi, vol. $2,565$. Translation adapted from Lynn, Classic of Changes, 87.

${ }^{77}$ Lunyu 6.18 in Lunyu zhushu (SSJZS; vol. 8), 54 [6: 7a]: 文質涁彬, 然後.尹尹尹 子子.

${ }^{78}$ N.B.: The distinction between different philosophical traditions and strata (vulgo: schools) is primarily useful as a scholastic attempt to systematize. Especially for periods characterized by syncretistic thinking, it tends to beguile the observer into foregone conclusions and oversimplifications. As a matter of fact, one should-especially in this case-probably never be too confident about suggesting any such clear-cut line.

${ }^{79}$ See the passages 'If wind and bone lack colour, eagles group together in the forest of litera-

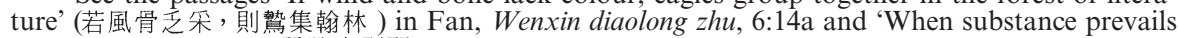
over style, it is crude' (質勝文則野) in Lunyu zhushu, 54 [6: 7a]. On Liu Zhen and his pentasyllabic oeuvre see Shipin, 01004.25-28 and Führer, Chinas erste Poetik, 243-6 [4.1.5].

${ }^{80}$ See the passages '[If] colour lacks wind and bone, pheasants jump around in the garden of letters' (采乏風骨, 則雉竄文直) in Fan, Wenxin diaolong zhu, 6:14a and 'When style prevails over substance, it is pedantic' (文勝質則史) in Lunyu zhushu, 54 [6: 7a]. On Wang Can and his pentasyllabic oeuvre see Shipin, 01004.29-31 and Führer, Chinas erste Poetik, 247-250 [4.1.6].
} 
Cao Zhi's poems exhibit the ultimate harmonic equilibrium (binbin 涁涁). His pentasyllabic oeuvre thus stands for the embodiment of perfect poetry. In other terms, Zhong Hong considered Cao Zhi the only poet who represented the personification of the ultimate (cultural) achievement, a realm described as 'singing phoenix' (ming feng 鳴鳳) by Liu Xie, and as 'accomplished person' (junzi 君子) in the Lunyu. ${ }^{81}$

In the light of Zhong Hong's intellectual biography, it is certainly no surprise that we can pinpoint a number of passages - mainly in crucial sequences of the Shipin - which allude to the Zhouyi. One example may suffice. Leaving aside that many 'joyful banquets' (jiahui 嘉會) were actually caused by one person leaving, and thus associated with the pain of separation, Zhong Hong stylistically juxtaposed jiahui with 'leaving one's friends' (liqun 離群; lit.: 'leaving the group/herd/flock'), as well as expressing affection (qin 親) with expressing resentment or grief (yuan 怨) through the medium of the shi. ${ }^{82}$ Notwithstanding that we observe significant semantic shifts, the tension between jia (zhi) hui 嘉(之)會 and liqun as reflected in this rhetorical device is anticipated in the 'Wenyan' 文言 (On words and phrases) commentary to hexagram Qian 乾 (Pure Yang / Heaven). ${ }^{83}$ In the Zhouyi, jia (zhi) hui is understood as 'assemblage of excellencies' or 'coincidence of beauty', but Zheng Xuan's explanation of the term qun 群 (group) as 'fellows and friends' (tongmen pengyou 同門朋友) opened the way for transferring the terms jiahui and liqun onto the topic of poetic creativity. ${ }^{84}$ With qun being perceived as a group within which genuine emotions are communicated, Zhong Hong's list of stimuli of poetic creativity finds its climax in the following shortened quote from the Lunyu:

[Pentasyllabic] poems can be used for socialising [and] for expressing resentment/grief. ${ }^{85}$

As seen from these examples, insights into Zhong Hong's approach should unquestionably not focus solely on the Zhouyi. Therefore, and despite the fact that this may seem trivial, it is necessary to emphasize that the influence of $r u$ scholarship as well as concepts developed in xuanxue 玄學 metaphysics, such as ziran 自然, ziwei 滋味 and so forth, left their distinct mark on the Shipin.

${ }^{81}$ See the passages 'Only where elegance [of the language] sparkles and [the content] soars high, we do have a singing phoenix in [the world of] literature' (唯澡耀而高翔, 固文筆之鳴鳳也) in Fan, Wenxin diaolong zhu, 6:14a and wen zhi binbin ranhou junzi in Lunyu zhushu, 54 [6: 7a]. On Cao Zhi and his pentasyllabic oeuvre see Shipin, 01004.17-24 and Führer, Chinas erste Poetik, 237-42 [4.1.4.]. Cf. also Bernhard Führer, 'Apotheosis of poets. Two modi operandi of the reasoned exercise of literary taste', in Tamkang Review, 24/2 (1993), 59-81.

${ }^{82} \mathrm{Cf}$. also Qian Zhongshu 錢鍾書, 'Shi ke yi yuan' 詩可以怨, in Wenxue pinglun 文學評論, 1981/1, 16-21 and Bernhard Führer, 'Die "schmerzvolle Klage" als Stimulus des chinesischen Dichters', in Raoul D. Findeisen and Robert H. Gassmann (ed.), Autumn floods 秋水. Essays in honour of Marián Gálik (Bern: Peter Lang Verlag, 1998 [Schweizer Asiatische Studien, 30]), 35-47.

${ }^{83}$ See the passages 'Heng is the coincidence of beauty. ... the coincidence of beauty is sufficient to accord with propriety' (亨者, 嘉之會也 ....嘉會足以合禮) in Zhouyi zhengyi, 12 [Qian. Wenyan; 1: 10a] and '[Although] advance and withdrawal have no constant norm, [one does] not leave his fellows/group' (進退無恒, 非離群也) in Zhouyi zhengyi, 14 [Qian. Wenyan; 1: 14b]; translations in the notes are adapted from Lynn, Classic of Changes, 130, 136. Cf. James Legge, ed. by Ch'u Chai and Winberg Chai, I Ching. Book of Changes (Repr.: New York: University Books, 1964), 408, 410, and R. Wilhelm, I Ging, 346f., 352.

${ }^{84}$ These two translations are from Legge, I Ching, 408 and Lynn, Classic of Changes, 130. On liqun see Zheng Xuan's and Lu Deming's notes on qun in Liji zhushu, 129 [Tan Gong. Shang; 7: 9 a].

${ }^{85}$ The sequence shi ... ke yi qun, ke yi yuan 詩... 可以群, 可以怨 from Lunyu 17.8 in Lunyu zhushu, 156 [17: 5b] and its shortened quote shi ke yi qun, ke yi yuan 詩可以群, 可以怨 in the Shipin, 01002.10 show different points of reference. Whereas in Lunyu the passage refers to the songs of the Shijing, Zhong Hong's interest lies in pentasyllabic shi-poems. The statement '[The] Songs can be used for socialising [and] for expressing resentment' thus turned into '[Pentasyllablic] poems can be used for socialising [and] for expressing resentment'. 
The first sentences of his preface ( $x u$ 序) to the Shipin may serve as a convenient illustration of the variety of textual layers. Zhong Hong's line of argument turns from the Liji 禮記 (Book of Rites) - perhaps an indication that the $l i$ 禮(rites) were one of the central concerns of his days ${ }^{86}$ - and the 'Mao Shi xu' 毛詩序 (Preface to Mao's [redaction of the] Songs) to the cosmic function of poetry which originates from the 'Shuo gua' and was further developed by Dong Zhongshu 董仲舒 (c. 197-c. 104 B.C.) during the Earlier Han (206 B.C. -25 A.D.). Following a short reference to the Shangshu, Zhong Hong's argument finally returns to the 'Mao Shi $x u$ ' but silently passes over the social therapeutic effects of shi featured there by Han classicists. In addition, a close reading of the first clauses of the preface reveals similarities in wording and thought with passages in the Zhuangzi, in a number of literary works of the Han periods, and in Xiao Yi's 蕭繹 (508-554) Jinlouzi 金樓子.87

\section{Technical considerations}

Like any other sophisticated work, the Shipin deserves to be read sub specie temporis and within its own semantic system. Although at first glance perhaps received only in passing, the biographers' statement about Zhong Hong's scholarship on the Zhouyi proved an extremely valuable pointer towards a more thorough reading of the Shipin.

There exists, however, the peril of such a remark leading to a monofocused approach which would consequently invite us to disregard the factual realities of intellectual history as well as the fact that the structure and the concepts exploited in the Shipin represent a multifaceted blend of scholarly traditions, philosophical strata and original insights.

On the one hand, attempts to uncover intertextual connections in the Shipin need to focus on Zhong Hong's evaluative comments which, sometimes in a tenuous and occasionally in a more transparent manner, correspond to passages found in poems written by the author discussed. In addition, such efforts need to address the more conceptual level, which is much more problematic to work on since identity in wording does not necessarily indicate identity of thought and concept. ${ }^{88}$ Indeed, when clauses or words are transferred from one text into another, semantic consistency is not the rule but merely the exception. In order to make the transmission and adaptation of ideas manifest, most of the referential clauses do, to varying degrees, call for a de-contextualization from their sources and a subsequent re-contextualization in the Shipin - or indeed any other work.

Though limited in number, the examples set forth some insights into the way in which philosophical strata and traditions are interwoven in the Shipin. The technique of pinpointing intellectual influences sheds light on an intricate textual fabric and its dynamics. Further to that, it also recalled the description of Zhong Hong as 'thoughtful on the ratio [of matters]', as a learned, analytical and original student of the reasoned exercise of literary taste.

\footnotetext{
${ }^{86}$ For an in-depth study of a number of important aspects of the ritual code during the Liang dynasty see Andreas Ernst Janousch, The reform of imperial ritual during the reign of Emperor Wu of the Liang dynasty (502-549) (unpublished $\mathrm{PhD}$ dissertation, Cambridge University, 1998).

${ }^{87}$ See Shipin, 01001.04-06; for more detailed references see Führer, Chinas erste Poetik, 61-70.

${ }^{88}$ In principle, this observation also applies to the comparison of the evaluative statements with the poems, though the degree to which this might become topical varies.
} 